\title{
Bacteria Present
}

National Cancer Institute

\section{Source}

National Cancer Institute. Bacteria Present. NCI Thesaurus. Code C120867.

Confirmatory presence of bacterial microorganisms. 